\title{
OVO Product Users' Sustainable Desire as an Challenger on Digital Payment Market (Case Study in West Jakarta)
}

\author{
Nuriman Novianto ${ }^{1}$, Didik J. Rachbini ${ }^{2}$, and Endi Rekarti ${ }^{3}$ \\ ${ }^{1,2,3}$ Magister Management, Posgraduate Program, Mercu Buana University \\ Jakarta, Indonesia
}

\begin{abstract}
This research aims to discover of which factor that could increase those sustainable desire of OVO digital wallet users in West Jakarta. Population based on research were user from OVO digital wallet in West Jakarta. Those sample was amounted to 310 respondents with nonprobability sampling technique as its technique preferably . To answer those problem formulation, objectives and hypothesis regarding this research, so it was sort of by Structural Equation Model (SEM) analysis tool and using IBM SPSS AMOS version 22 tools. These reseach has results which shown that: Product quality has an good and strongly reacted over sustainable desire. Ease of use also has peak and positive towards impact to sustainable desire. The merchant's image has an conclusive and remarkable influence towarda sustainable desire. Online promotion has beneficial and significant impact over sustainable desire. While Customer Perceived value has practical reaction towards sustainable desire. Not of that this Customer perceived value also could transform as an intervere variable which affects product quality, ease of use, merchant's image and online promotion to continuous interest to use OVO digital wallets.
\end{abstract}

Keywords:- Product quality, easy to use, merchant image, online promotion, customer perceived value and sustainable desire.

\section{INTRODUCTION}

Internet has an important role and beneficial impact in each days life. One country that get lots of benefits from internet is Indonesia. Indonesia is a country with population of 262 million and these internet users in 2017 reached 143.26 million - APJII (2017).

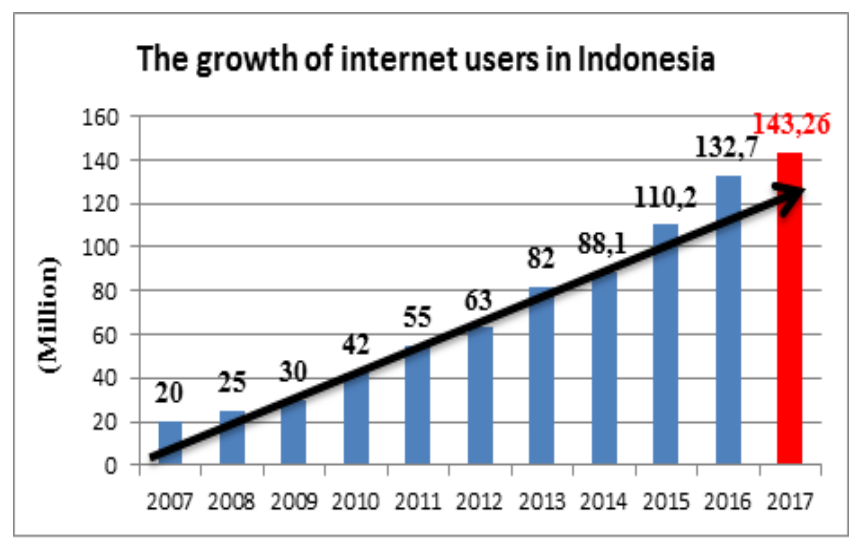

Fig. 1:- Internet Growth in Indonesia 2007-2017

Source: APJII- Indonesian Internet Service Providers Association (2018)

An Internet use in terms of improving those business networks, sales and transactional products or services by the use electronic commerce. These current phenomenon on society is they do not want to be bothered by transactions and which manifested by cashless habits. As well as busy activity and changes in people's habits in conducting by online transactions. Moreover, these occurs because of support from Indonesian government aswell by promoting the National Non-Cash Movement (GNNT). With these government support therefore it appears those companies who engaged in financial technology. Based on data from $\mathrm{CNBC}$ Indonesia, the most widely used financial technology business is to carrying out payments needs.

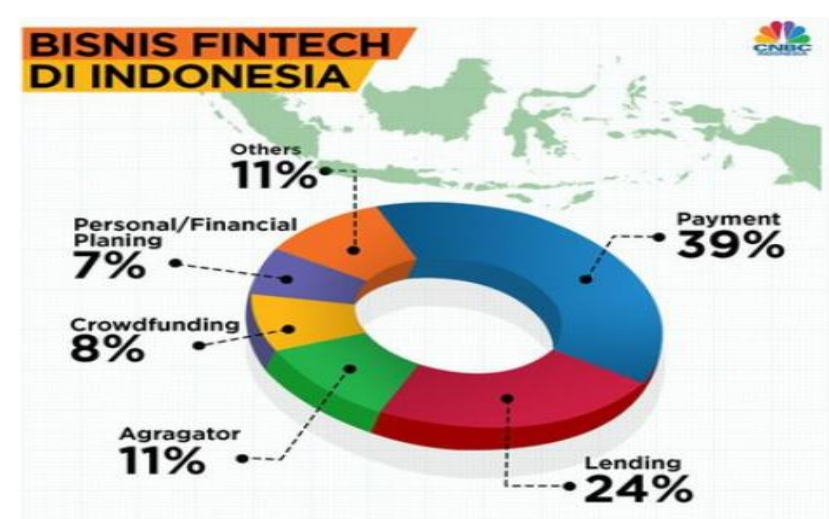

Fig. 2:- Fintech business in Indonesia Source: CNBC Indonesia (2018) 
OVO is a digital payment business owned by Lippo Group which was established in 2017. As a market challenger in digital payment industry which led by GoPay, OVO uses a frontal and side attack strategy to restrain the pace of growth or even capture GoPay's market share in digital payment industry. OVO users and merchants are growing rapidly, it could be said that exceed GoPay users and merchants, but it is not directly proportional to the percentage of service still under GoPay. It also could be seen that the greater number of OVO users and merchants it does not provide greater number of transactions compared to GoPay, where OVO only reaches 1,000,000,000 transactions and GoPay has reached 4,350,000,000 transactions.

\begin{tabular}{|c|c|c|c|c|c|}
\hline Comparison/User Grow th & Early 2017 & End 2017 & Early 2018 & End 2018 & $\begin{array}{c}\text { Number of Transascion } \\
2018 \\
\end{array}$ \\
\hline \multicolumn{6}{|c|}{ OVO } \\
\hline User & $7,000,000$ & $15,000,000$ & $28,750,000$ & $115,000,000$ & \multirow{3}{*}{$1,000,000,000$} \\
\hline Served Percentage & $0.01 \%$ & $0.13 \%$ & $0.74 \%$ & $0.43 \%$ & \\
\hline Services/Merchant & 8,75 & 750 & 134 & 230 & \\
\hline \multicolumn{6}{|c|}{ GoPay } \\
\hline User & $11,000,000$ & $15,000,000$ & $27,500,000$ & $40,000,000$ & \multirow{4}{*}{$4,350,000,000$} \\
\hline Merchant & 125 & 300 & 400 & 450 & \\
\hline Served Percentage & $1.14 \%$ & $2 \%$ & $1.45 \%$ & $1.13 \%$ & \\
\hline Services/Merchant & 88 & 50 & 69 & 89 & \\
\hline
\end{tabular}

The problems which faced by OVO as it could be seen from giving stars percentage in each apps development. The percentage of giving 1 star as always in second highest position in each apps development. Those stumbled consist of product complaints, difficulties to use and those problem occurs when using promos. OVO digital wallet apps could be catagories as the top financial apps, but behind these highest ranks there's so many complaints given by users and this should be considered as improvement to get more transactions by this apps.

\begin{tabular}{|c|c|c|c|c|c|c|c|}
\hline Apps Development/ Rating Star & 5 & 4 & 3 & 2 & 1 & Total reviewer & TOP Rank \\
\hline Playstore & 80,774 & 9,908 & 4,793 & 2,571 & 11,937 & 109,983 & \multirow{2}{*}{4} \\
\hline Percentage & $73 \%$ & $9 \%$ & $4 \%$ & $2 \%$ & $11 \%$ & $100 \%$ & \\
\hline Appstore & 2,678 & 850 & 464 & 396 & 1,512 & 5,900 & \multirow{2}{*}{1} \\
\hline Percentage & $45 \%$ & $14 \%$ & $8 \%$ & $7 \%$ & $26 \%$ & $100 \%$ & \\
\hline
\end{tabular}

Table 2:- Those Rating given to OVO Applications in Apps Development

Sources : Secondary Data (2019)

From these secondary data which author has obtained subsequently conducts pre-research with survey method as an identification from problem that studied. The pre-survey was carrying out by giving questionnaires to 30 respondents who had transacted with OVO digital wallets in West Jakarta. From these pre-research results, five main factors which influence those continuous desire to use OVO digital wallets in West Jakarta, such as product quality, ease of use, merchants image, online promotion and customer perceived value. Based on these explaination, the researchers then applied for paper which entitled "OVO Product Users' sustainable desire as an Challenger on Digital Payment Market (Case Study in West Jakarta".

\section{THEORETICAL REVIEW}

\section{A. Product Quality}

According to Schiffman and Kanuk in Gulliando and Basri (2019) product quality is the ability from a company to provide an identity or feature on each of its products so consumers could recognize these product. Meanwhile, according to American Society for Quality Control in Desyana and Basri (2019) explains that product quality is the overall characteristics and nature of a product or service that could affects its ability to satisfy or implied needs. 


\section{B. Easy to Use}

Davis in Saidani, et, al.(2018) defines that ease of use is a level where someone believes that about certain systems that could decrease someone's efforts on doing something. He further explained that the perceived of easy to use on its use has huges impact towards the user's intention to use something.

\section{Merchant Image}

Based on Peter \& Olson (2005) they said that merchant's image is what consumers think about particular store. While according to Solomon (2018)he defines those merchants image as a perception related to merchandise, physical environment, type of store and perceived service quality. Merchant image could generate an perception and impression from customers.

\section{Online Promotion}

According to Simamora in Ali, et.al. (2018) Promotion is any form of communication that used to inform, persuade or remind people about products which eventually generated by organizations, individuals or households. Samosir and Prayoga (2015) further explained that online promotion is a communication tool that consist of a combination of tools used by companies online, such as online advertising, online complaint services, online discounted pricing and online gift giving.

\section{E. Customer Perceived Value}

Kotler and Keller (2016: 151) explained that Customer perceived value is the difference between evaluating from prospective customers to all benefits and costs offers and perceived alternatives. Furthermore Zeithaml in Cevik and Mittal (2016: 184) explains that customer perceived value has defined as an assessment of the whole package by customers based on usefulness of a product and perceptions about what is received.

\section{F. Sustainable Desire}

According to Bhattacherjee (2001) sustainable desire (continuance intention) has defined as satisfaction form by customers or users who has higher levels of behavioral outcomes in form of repurchase intentions or desires to continue using products or services. Furthermore, according to Mantymaki, et. al. (2014) sustainable desires (continuous intention) also defined as an interest to continue or to participate and take part in particular system.

\section{G. Theoretical Framework}

Changes of customer activities could be explained by analyzing these influence from product quality, Ease of use, Merchant's image and promotional programs alongside customer perceived value as an intervern variable. Those analysis concept of changes in customers' sustainable interest can be beared as in these theoretical framework diagram as in belows:



Fig. 3:- Theoretical Framework

\section{H. Hypothesis}

Addressing to literature review and theoretical framework which described above, those hypothesis could be developed and proposed as in follows:

$>$ Product quality has an influence over sustainable desire to use OVO digital wallet users.

$>$ Easy to use has an affection over continuous intention to use OVO digital wallet users.
Those merchant's image has an influences over sustainable desire to use OVO digital wallet users.

$>$ Online promotion has an impact towards sustainable intention to use OVO digital wallet users.

$>$ Product quality has an influences continuous with those customer perceived value as an intervene variable on OVO digital wallet users. 
Ease of use affects the ongoing interest with the perception of customer value as an intervening variable on OVO digital wallet users

The merchant's image has an influences towards sustainable interest with customer perceived value as an intervene variable on OVO digital wallet users.

$>$ Online promotion has an influence towards continuous intentions with customer perceived value as an intervene variable on OVO digital wallet users.

$>$ Customer perceived value has an impact over sustainable interest in using OVO digital wallet users.

\section{METHODOLOGY}

These research was design by causality analysis to discover causality relationship between these research variables based on hypothesis arranged. As for gained information it spreads survey to respondents in form of questionnaire. In this research, The researchers has an interested to examined about influence from independent (exogenous) variables that consist of product quality, Ease of use, merchant image and online promotion to dependent variable (endogenous) which is, sustainable interest thats influenced by intervening variables such as customer perceived value towards OVO digital wallet users at merchants in West Jakarta area.
These population were users of OVO digital wallets in West Jakarta. The sampling technique used nonprobability sampling by purposive sampling method. The sample sized was find out based on analysis method that used. According to these guidelines, the number of samples in this research were $5 \times 62=310$ respondents.

Analysis method in this research done by the help of Structural Equation Modeling (SEM)and used Analysis of Momment Structure (AMOS) program. Purpose of these data analysis method is to Interpreted and draw several conclusions from number of data that collected and also use the Structural Equation Modeling (SEM) program, which is a combination from factor analysis and regression analysis.

\section{RESULTS AND DISCUSSIONS}

\section{A. Demographic Characteristics of Respondents}

Following on characteristics from 310 respondents who are OVO digital wallet users in West Jakarta, it can be described that most majority of OVO users were women $(56.77 \%)$ aged between $17-25$ years $(40.97 \%)$ who has bachelor's degree $(43.55 \%)$ and work as employees $(31.61 \%)$. So it could be defined that OVO digital wallet users in West Jakarta are productive age workers who work in offices and have high mobility.

\begin{tabular}{|c|c|c|c|}
\hline No. & Description & Frequency (Person) & Percentage (\%) \\
\hline \multirow{3}{*}{1} & Gender & & \\
\hline & Male & 134 & 43.23 \\
\hline & Female & 176 & 56.77 \\
\hline \multirow{5}{*}{2} & Ages & & \\
\hline & $<17$ years & 25 & 8.06 \\
\hline & $17-25$ years & 127 & 40.97 \\
\hline & $26-35$ years & 96 & 30.97 \\
\hline & $>35$ years & 62 & 20.00 \\
\hline \multirow{6}{*}{3} & Last Education & & \\
\hline & Juni or High School & 9 & 2.90 \\
\hline & Senior High School & 48 & 15.48 \\
\hline & Diploma & 86 & 27.74 \\
\hline & Degree & 135 & 43.55 \\
\hline & $=$ Master Degree & 32 & 10.33 \\
\hline \multirow{6}{*}{4} & Profession & & \\
\hline & Student & 28 & 9.03 \\
\hline & Student of University & 86 & 27.74 \\
\hline & Employee & 98 & 31.61 \\
\hline & Entrepreneur & 37 & 11.94 \\
\hline & Public Servants /Soldiers/ Polices & 61 & 19.68 \\
\hline
\end{tabular}

Table 3:- Demographic Characteristics of Respondents

\section{B. Model Sizing Test}

Sizing model test is examined from those relationship between indicators and latent variables. Validity test in this research used confirmatory factor analysis (CFA) test, while reliability test used a composite reliability measure and variance from extracted measure. From these results of validity test it is known that $\mathrm{CR}$ value from all these research indicators has an value $>2.58$, so it could be said valid. 




Fig. 4:- Confirmatory Factor Analysis Test Results for Exogenous and Endogenous Variables

Reliability test results also showed that all research variables had $\mathrm{CR}>0.7$ and $\mathrm{VE}>0.5$, so it concluded that reliable.

\begin{tabular}{ccc}
\hline \multirow{2}{*}{ Latent Variable } & \multicolumn{2}{c}{ Reliability } \\
\cline { 2 - 3 } & $\mathbf{C R} \geq \mathbf{0 , 7 0}$ & $\mathbf{V E} \geq \mathbf{0 , 5 0}$ \\
\hline Product Quality (X1) & 0.978 & 0.737 \\
\hline Easy to Use (X2) & 0.975 & 0.765 \\
\hline Merchant Image (X3) & 0.974 & 0.755 \\
\hline Online Promotion (X4) & 0.960 & 0.752 \\
\hline Customer Percevied Value (Z) & 0.953 & 0.669 \\
\hline Sustainable Desire (Y) & 0.865 & 0.617 \\
\hline
\end{tabular}

Table 4:- Reliability Test Results

\section{Model Fit Test}

Accordance to model fit test, it was found that sample size met minimum requirements > 100; data from indicator also normally distributed and suitable for use because all indicators has critical ratio values below \pm 2.58 ; and there's no data that have $\mathrm{p} 1$ and $\mathrm{p} 2$ values $<0.001$.

\section{Hypothesis Examinations}

Connection between constructs in hypothesis was shown by regression weights value, to discover more clearly about those influence which came from product quality (X1), ease of use (X2) merchant image (X3) and online promotion $(\mathrm{X} 4)$ to customer perceived value $(\mathrm{Z})$ and sustainable desire (Y) for OVO digital wallet users like could be seen from Table 5 below.

\begin{tabular}{cccccccc}
\hline \multicolumn{2}{l}{ Relation ship Between Constructions } & Estimate & S.E. & C.R. & P & Information \\
\hline MB & $<---$ & KP & 0.301 & 0.044 & 6.777 & $* * *$ & Positive and Significant Influence \\
\hline MB & $<---$ & KM & 0.125 & 0.031 & 4.075 & $* * *$ & Positive and Significant Influence \\
\hline MB & $<---$ & CM & 0.130 & 0.035 & 3.761 & $* * *$ & Positive and Significant Influence \\
\hline MB & $<---$ & PP & 0.191 & 0.032 & 5.999 & $* * *$ & Positive and Significant Influence \\
\hline MB & $<--$ & NPP & 0.281 & 0.046 & 6.147 & $* * *$ & Positive and Significant Influence \\
\hline
\end{tabular}

Table 5:- Hypothesis Examination Results (Direct Effect) 
Based on P-Values of product quality is $0.000<0.05$ so it could be said to be significant with estimate value is positive that is 0.301 , meaning that product quality has positive impact towards Sustainable desire of $30.1 \%$. Therefore H1 hypothesis in this research was accepted.

Following on P-Values value of ease of use is $0,000<$ 0.05 so it could said that it was significant with estimate value is positive that is equal to 0.125 meaning that ease of use has positive influence over continuous interest by $12.5 \%$. So $\mathrm{H} 2$ hypothesis in this research was accepted.

$>$ Based on P-Values of the merchant's image is $0,000<$ 0.05 so it was described as significant and estimate value was positive thats equal to 0.130 which means that merchant's image has mutual reaction against sustainable interest of $13.0 \%$. Thus H3 hypothesis was accepted.
> According to P-Values of online promotion was $0.000<$ 0.05 so it could be said was significant with estimated value was positive, that is 0.191 , that means online promotion has huge impact to sustainable desire of $19.1 \%$. Thus H4 hypothesis was accepted.

$>\mathrm{P}-\mathrm{Values}$ from customer perceived value is $0,000<0.05$ or its said was significant with estimate value was positive equal to 0.281 which means that online promotion has huge effect to continuous interest of $28.1 \%$. Therefore H9 hypothesis was accepted.

To see about indirect affect from product quality, ease of use, merchant image and online promotion against sustainable desire through customer perceived value like could be seen in Table 6 below.

\begin{tabular}{|c|c|c|c|}
\hline Relationship Between Constructions & Estimate & $\mathbf{P}$ & Information \\
\hline \multicolumn{4}{|c|}{ Direct Effect on Customer Perceived Value } \\
\hline KP $>$ NPP & 0,271 & **** & Positive and Significant Influence \\
\hline $\mathrm{KM} \rightarrow \mathrm{NPP}$ & 0,154 & **** & Positive and Significant Influence \\
\hline $\mathrm{PP} \rightarrow>\mathrm{NPP}$ & 0,260 & **** & Positive and Significant Influence \\
\hline \multicolumn{4}{|l|}{ Indirect Effect on Sustainable Desire } \\
\hline $\mathrm{CM} \rightarrow \mathrm{NPP} \rightarrow \mathrm{MB}$ & 0,051 & $* * *$ & Positive and Significant Influence \\
\hline $\mathrm{PP}->\mathrm{NPP} \rightarrow \mathrm{MB}$ & 0,073 & $* * *$ & Positive and Significant Influence \\
\hline
\end{tabular}

Table 6:- Hypothesis Examination Results (Indirect Effect)

The test results show that P-Values $=0.000<\alpha=0.05$ and estimated value is positive which equal to $0.271 \mathrm{x}$ $0.281=0.076$ meaning that product quality has an mutual impact towards sustainable interest through customer perceived value is $7.6 \%$. Therefore H5 hypothesis was accepted.

$>$ The test results show that P-Values value $=0,000<\alpha=$ 0.05 and estimate value is positive which equal to 0.154 $\mathrm{x} 0.281=0.043$ meaning that product quality has an beneficial reacted to sustainable desire through customer perceivrd value of $4.3 \%$. So H6 hypothesis in this research was accepted.

$>$ The test results show that P-Values $=0.000<\alpha=0.05$ and estimate value is positive which equal to $0.180 \mathrm{x}$ $0.281=0.051$ meaning that product quality has mutual reaction over continuous interest through customer perceived value of $5.1 \%$. Thus $\mathrm{H} 7$ hypothesis was accepted.

$>$ The test results show that the P-Values $=0.000<\alpha=$ 0.05 and estimated value is positive which equal to $0.260 \times 0.281=0.073$ that means these product quality has positive influence to sustainable desire through customer perceived value of $7.3 \%$. Therefore H8 hypothesis was accepted.

\section{E. Determination Coefficient Test}

The structural model evaluation was done by looking at determination coefficient Based on the estimated value, it could be explained that customer perceived value is 0.687 , or this shows that $68.7 \%$ customer perceived value could be influenced by product quality, Easy to use, Merchant image and online promotion while remaining $31.3 \%$ was influenced by other variables outside these research. These estimated value of sustainable desire is 0.951 , or shows that $95.1 \%$ of Sustainable desire could be influenced by product quality, ease of use, merchant image, online promotion and customer perceived value while those remaining $4.9 \%$ was influenced by other variables outside researched.

\begin{tabular}{|c|c|}
\hline \multicolumn{2}{|c|}{$\begin{array}{l}\text { Squared Multiple Correlations: } \\
\text { (Group number } 1 \text { - Default model) }\end{array}$} \\
\hline Variable & Estimate \\
\hline NPP & 0.687 \\
\hline MB & 0.951 \\
\hline
\end{tabular}

Table 7:- Determination Coefficient Test Results

\section{F. Discussions}

Product quality has an influences to continuous interest on using OVO digital wallets. These findings were in line with previous research which conducted by Chang, et. al. (2018)that revealed if product quality has significantly reacted over sustainable interest. product quality has an important role in achieving someone's perception of product performance from that product itself, so they will show special interest to use that product continuously. Products qualities which offered by OVO digital wallets is not only link to product performance, but also could be relied upon. OVO digital wallet products is 
very well used in various merchants spread throughout Indonesia, so customers do not need to worry if they will make payments. For this reason, OVO should develop new innovations product by modifying existing payment systems therefore it would increasing those customers interest to use OVO digital wallets.

Easy to use has an affects to continuous interest on using OVO digital wallets. These findings were in line with prior results from Hou (2015) research which revealed that Ease of use has significantly reacted towards sustainable interests. Ease of use will cause users to make little effort to operate and also will accustomed to use OVO digital wallets. Beside that, ease of use of a product also greatly influenced by appearance of product itself so it would be so easy to understand and use by all ages, with all facilities that provided, so it will increase customer interest to use OVO digital wallet.

Merchant's image also has influences against these continuous interest in term using of OVO digital wallets. These results does similiar with prior result fromWatanabe, et. al.(2019) research which found that continuous interest in term of use financial technology products have to enhanced, one of way by improving those merchants image such as collaborating merchants. According to these result, those factors who greatly influence those merchant image on OVO is competitive price of product and good vibrant of merchant. Prices offered by merchants who team up with OVO should be based on quality offered by merchants so customer would fully satisfied with merchant's product and indirectly have an impact on customer interest. Beside that, those vibrant from merchant also has an impact to customer's interest in term shop using OVO digital wallet. By creating good atmosphere in accordance with what is desired, especially for millennials who in fact are the most OVO digital wallet users will invite them to flock to the merchants they wanted. This sign could be use utilized by OVO to continuing its develop business ideas with existing merchants and create these intended atmosphere.

Online promotion has an impact towards sustainable interest in term using OVO digital wallets. These results were in line with results from previous research which conducted by Sartika (2017) she suggests that a person's continuous desire in using financial technology products is highly dependent on online promotion that provided by a company or product, such as giving cashback or discounts. Based on these research and observations made, by giving cashback OVO should utilize the events which conducted by merchants that have collaborated so beside these cashback given to attract customers, those events that are held will also be a magnet of its own to increase customer interest in using OVO digital wallet at merchant.

Product quality has an impact over continuous interest through customer perceived value for OVO digital wallets. These findings were similiar with results by Putri (2016) which found that customer perceived value could be an intervere variable and connecting an influence between product quality to continuous interest to use financial technology product. With products quality that offered by OVO digital wallets, users would feel satisfaction in terms of prestige. With this assumption, OVO needs to improve product quality, especially for OVO Premier which sign of prestige while using OVO digital wallet.

Ease of use has an effect on continuing interest through the perception value of OVO digital wallet customers. The findings were in line with prior studies from Lee, et. al (2017) who found that Easy to use of a product will increase someone's perception about benefits value which obtained and will foster a person's continued interest in using that product. This means that OVO should try to create those positive experiences in customers minds so when communicating with them. This will make it easier to find the stuff they wanted, convenience of ordering, creating trust by maintain customer data and use of OVO digital wallets at merchants that have collaborated.

The merchant's image has an reaction to sustainable interest viewed from customer perceived value aswell. These outcome has similiar with prior results from Hanchi, et. al. (2016) it was revealed that merchant's image has huge impact over sustainable desire through customer perceived value. It is proves that merchant's image is dominant enough to create a good value perception in eyes of OVO digital wallet users, so OVO should be fixing up those existing merchant's image. OVO could also take some of advantage from an extensive merchant network and develop existing digital wallet applications to make it more attractive infact customers will feel the difference between these products offered and others services from competitors so OVO digital wallet would always come up in minds of its users.

Online promotion has an affects towards sustainable interest through customers perceived value variable. These outcome were in line with prior results from Alamsyah (2018) which found that online promotion has strong influence over continuous interest through customer perceived value. Online cashback promotion on OVO digital wallets is one of the main attractions for users, this could be increased through the expansion of OVO digital wallets at merchants. With these expansion and combined with existing cashback program, it would create a good customer perception on OVO digital wallets. This of course will create those indirect promotions that conducted by users through word of mouth so OVO digital wallets users will increase.

Customer perceived value towards sustainable desire in using OVO digital wallets. The findings were in line with previous research results which conducted by Hsiao, et. al. (2019) who found that perceived value which embedded in customers had huge mutual direct impact to continuous interest in using financial technology products. The value of customer perception can be increased through the customer's intention to use cashless. This encouragement could be created through customer trust and customer satisfaction with OVO digital wallet products. If these customer were satisfied with service offered by OVO 
digital wallet, so customer will be encouraged to use it and has implications to increasing customer interest in using OVO digital wallet.

\section{CONCLUSION AND SUGGESTION}

\section{A. Conclusion}

According to those analysis and also from Research results, these several following conclusions could be made up as:

$>$ Product quality has definite and remarkable impact towards those continuous desire to use OVO digital wallets in West Jakarta.

$>$ An Ease to use has an good and strongly influence over those sustainable desire to use OVO digital wallets in West Jakarta.

$>$ The merchant's image has an crucial and significant affect to an Continuous desire to use OVO digital wallets in West Jakarta.

$>$ Online promotion has an positive and remarkable reaction on sustainable desire to use OVO digital wallets in West Jakarta.

$>$ Product quality has an good and significant sign on impact towards sustainable desire through the perceived value of OVO digital wallet customers in West Jakarta.

$>$ An Ease of use has positive and remarkable effect against sustainable desire through those perception value of OVO digital wallet customers in West Jakarta.

$>$ The merchant's image has positive and significant influence to sustainable desire viewed from those perception value of OVO digital wallet customers in West Jakarta.

$>$ Online promotion has positive and significant effect on continuous desire viewed from those perception value of OVO digital wallet customers in West Jakarta.

$>$ The value of customer perception has an huge and strong impact against continuous desire to use OVO digital wallets in West Jakarta.

\section{B. Suggestion}

There has so many suggestions that authors created for OVO management those are as in follows:

$>$ OVO management is advised to sort out every problems faster while use the apps. The complaint service need to be done through 24-hour call center, 24-hour live chat, email response and social media there should be no more than 24 hours without visit to OVO merchant in advance to save OVO users' time.

$>$ OVO management is advised to pay more attention to the contents of application. The content is expected to be easier to use and quickly respond to user desires without buffering for too long beside it would get easier to use, users also could be efficient to use the time while using OVO digital wallet application.

$>$ OVO management is advised to evaluate those merchants who have collaborated and added more various merchants such as a merchants who collaboration with film companies or content creators therefore these kind of merchants could be directly added to the list of digital content available in application.
OVO management is advised to provide complete information regarding promotions through OVO websites and applications keeping up-to-date and future manner. Providing complete online information will make it easier for users to read and understand what promotions are available every day and also get knowledge enough about terms and conditions from ongoing promos.

$>$ OVO management is expected to improve those products offered, in this case about some of existing digital content. By increasing the quality of digital content, users will have more positive perception about OVO so it will have an good impact on increasing the number of sustainable users for OVO applications.

$>$ OVO management is advised to added some of attractive features thats simpler, more flexible and easily understood by all ages. From this, users would provide positive perception of OVO which have an impact on sustainable desire to use OVO digital wallets.

$>$ OVO management is advised to foster a positive merchant's image to merchant's users or visitors through creation of merchant environment which comfortable, safe, and conducive. Therefore, OVO management needs to form as special team to build merchants so they could build up and realize about customer satisfaction and loyalty, once the customer has a good perception assessment they would continue to do a transaction using OVO at merchant.

$>$ OVO management is advised to continue provide an attractive online promotions. The online promotion can use those merchants who have collaborated with OVO, for example by creating a special platform in merchant application, therefore users would feel those benefits which offered by OVO and will have an impact on sustainable desire to use OVO digital wallets.

$>$ OVO management is advised to create an offers that could benefit users through pricing data packages, phone credits and payment of electricity bills which cheaper than existing offline stores, so OVO users would feel those benefits offered and will have an impact to reusing OVO applications.

\section{REFERENCES}

[1]. Alamsyah, Hartadi. (2018). Analisa Pengaruh Mediasi Referral Wom Terhadap Loyalitas Yang Dipengaruhi Oleh Relationship Management dan Perceived Value (Studi Kasus Pengujian Produk B2B Oleh Pihak Ketiga). Thesis, Universitas Mercu Buana Jakarta.

[2]. Ali, Hapzi, Evi Narulita dan Adi Nurmahdi. (2018). The Influence of Service Quality, Brand Image and Promotion on Purchase Decision at MCU Eka Hospital. Saudi Journal of Business and Management Studies, 3(1): 88-97.

[3]. Bhattacherjee, A. (2001). Understanding Information Systems Continuance: An ExpectationConfirmation Model. MIS Quarterly, Vol. 25 No. 3, hal. 351-370. 
[4]. Cevik, S., Simsek, H., \& Mittal, H., (2016). "Social \& Economic Dynamics of Development: Case Studies". United Kingdom: IJOPEC Publication.

[5]. Chang Y-M., Cai C-M., Chang F-Y., (2018). "The influences of belief disconfirmation and country image on repurchasing intention for online sportswear: Empirical evidence from taiwan". Taiwan.

[6]. Desyana, dan Har Adi Basri. (2019). The Influence of Brand Image, Product Quality, Brand Awareness on Satisfaction and the Impact on Customer's Loyalty of PT. Altindo Mulia. International Journal of Innovative Science and Research Technology, 4(8).

[7]. Gulliando, Diego dan Muchsin S. Shihab. (2019). The Effect of Product Quality, Price and Promotion on the Purchase Decision of Telkomsel Service Products. International Journal of Innovative Science and Research Technology, Vol. 4, Issue 9.

[8]. Hanchi, Ye., Yun, Luo., (2016) "The Research on the Impact of Service Failure Severity on Customer Service Failure Attribution in the Network Shopping". Zhonguan University of Economics and Law, China.

[9]. Hou, C.-K. (2015). "Understanding Business Intelligence System Continuance Intention: An Empirical Study of Taiwan's Electronics Industry. Information Development, 1-13."

[10]. Hsiao, C.-H., Chang, J.-J., \& Tang, K.-Y (2019). "Exploring the influential factors in continuance usage of mobile social apps: Satisfaction, habit, and customer value perspectives". Telematics and Informatics. Taiwan.

[11]. Kotler, Philip \& Kevin Lane Keller. (2016). "Marketing Management (Fifteenth Edition)". New Jersey:Pearson Prentice Hall.

[12]. Lee, Y-E., Lee, B-S., Jeon, J, J, Y., (2017). “Factors influencing the behavioral intention to use food delivery apps". Social Behaviour and Personality. Republic of Korea.

[13]. Mantymaki, M.., J. Merikivi, T. Verhagen, F. Feldberg dan R. Rajala. 2014. Does A Contextualized Theory Of Planned Behavior Explain Why Teenagers Stay In Virtual Worlds?. International Journal of Information Management 34: 567-576.

[14]. Peter, J. P., \& Olson, J. C. (2005). "Consumer Behaviour dan Marketing Strategy ( $7^{\text {th }}$ ed)". New York : McGraw-Hill/Irwin.

[15]. Putri, Laurensia Hanjani. (2016). Faktor-faktor yang Mempengaruhi Minat Pembelian Ulang Terhadap Produk Naget Delicy. Jurnal Manajemen dan StartUp Bisnis, 1(2).

[16]. Saidani, B., Laksmi, A.R., Aditya, S., (2018) "Analisis pengaruh brand awareness, product quality dan ease of use terhadap customer perceived value pada e-money mandiri e-toll card". Jurnal Riset Manajemen Sains Indonesia. Universitas Negeri Jakarta, Jakarta.
[17]. Samosir, H.B.C., Prayoga, A.B (2015) “Jurnal Pengaruh Persepsi Harga dan Promos Terhadap Keputusan Pembelian Konsumen Produk Enervon-C". Jurnal Ilmiah Manajemen dan Bisnis. Mercu Buana University.

[18]. Sartika, Dewi. (2017). Analisis Faktopr-faktor yang Mempengaruhi Minat Beli Ulang produk You C 1000 Serta Dampaknya Terhadap Loyalitas Konsumen.Jurnal Penelitian Ekonomi dan Bisnis, 2(1): 10-21.

[19]. Solomon R. M., (2018), "Consumer Behavior; Buying, Having, and Being (12 $\left.2^{\text {th }}\right)$ ". Pearson

[20]. Watanabe E. A. de M., Torres C. V., \& Alfinito S., (2019). The impact of culture, evaluation of store image and satisfaction on purchase intention at supermarkets. Universidade de Brasilia, Brazil. 